$9^{\circ} 4$. Its place for $1885^{\circ} \mathrm{O}$ is in R.A. $19 \mathrm{~h} .27 \mathrm{~m} \cdot 35^{\circ} 5^{\mathrm{s}}$., N.P.D. $72^{\circ} 29^{\prime} 54^{\prime \prime}$.

Nos. $2577-78$ of the Astronomische Nachrichten contain the late Prof. Julius Schmidt's results of observations of variable stars made at Athens in 1883 , which were communicated about a fortnight before his sudden decease.

\section{ON THE AURORA BOREALIS IN ICELAND}

$A S$ considerable doubt has hitherto prevailed as to the form and nature of the aurora borealis in Iceland, I bave decided to pass the winter here in Reykjavik, in order to study the phenomenon on principles which I followed during my sojourn at Kautokeino la:t winter, 1882-83 (NATURE, vol:. xxvii. p. 394, and xxviii. p. 397).

I arrived here about the middle of October last, and began my regular observations on November 6 ; and although the zeries of observations as yet is brief, and, through very unfavourable weather, not so complete as might be desired, I believe that a few preliminary remarks on this phenomenon may not prove without interest, particularly as the appearance of the aurora borealis here is somewhat different to what we might expect and what is generally assumed.

Weather more unfavourable than I have encountered since my arrival it is impossible to imagine. A sky nearly always cloudy, rain, snow, and storm following upon storm-such have its chie characteristics been. A clear sky is quite an exception, and when it occurs there is a wind blowing so keen and cutting that no human being can walk out of doors for any length of time. Iceland is, no doubt, not favoured with very congenial weather, but such a winter as the present must, according to the dwellers here, be considered as quite an exceptional one.

I have shown in Table $I$. the average cloud calculations of each evening hour (the observations begin generally at 5 p.m., and continue until two or three hours after midnight) from November 6 to January 28 . Here 5 indicates the hour from $5 \mathrm{~h}$. t 5 h. $59 \mathrm{~m}$., \&c. The scale is the usual one, viz. from o (clear) to Io (cloudy).

TABLE I.

\begin{tabular}{lll|l|l|l|l|l|l|l|l|l|l|l|l} 
Hour & $\ldots$ & $\ldots$ & 5 & 6 & 7 & 8 & 9 & Io & $\mathrm{rr}_{\mathrm{r}}$ & $\mathrm{r}_{2}$ & $\mathrm{r}_{3}$ & $\mathrm{r}_{4}$ & $\mathrm{I}_{5}$ Average
\end{tabular}

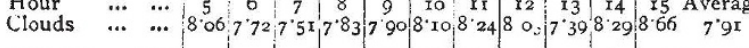

If an average of the nebulosity on each evening be taken, each value of the scale will fall on the number of days shown in Table 11. The former are also calculated in per cents. of the total days $(83)$.

TABLE II.

\begin{tabular}{|c|c|c|c|c|c|c|c|c|c|c|}
\hline $\begin{array}{ll}\text { Clouds } & \ldots \\
\text { Lays } & \ldots\end{array}$ & $\begin{array}{l}0 \\
2\end{array}$ & $\begin{array}{l}\mathrm{T} \\
8\end{array}$ & $\begin{array}{l}2 \\
2\end{array}$ & \begin{tabular}{l|l}
3 & 4 \\
1 & 4
\end{tabular} & $\begin{array}{l}5 \\
1\end{array}$ & $\begin{array}{l}6 \\
x\end{array}$ & $\begin{array}{l}7 \\
9\end{array}$ & $\begin{array}{l}8 \\
9\end{array}$ & $\begin{array}{r}9 \\
\mathbf{1 5}\end{array}$ & $\begin{array}{l}\text { IO } \\
3 \text { I }\end{array}$ \\
\hline \multirow[t]{2}{*}{ Per cent. } & 12.4 & 9.6 & 24 & $1.2 \mid 4^{\circ}$ & $1 \times 2$ & & 10.8 & 10:8 & $18 \%$ & 373 \\
\hline & & 4.5 & & $7: 2$ & & & 229 & & & \\
\hline
\end{tabular}

These figures speak so plainly for themselves that any comment is needless.

Through Iceland being situated in the zone of the terrestrial magnetism, it might be assumed that the aurora borealis attained a high degree of development and splendour here; but this has not been the case this winter, in Reykjavik at all events, even allowing for the unfavourable weather. The auroræ here are generally faint and wanting in force; it is only seldom that there is any energy in the movements, and but rarely that the forms are sharply defined, while the outlines are dim and vague.

There have therefore only been a few occasions on which I have been able to effect somewhat satisfactory mearurements with the auroral theodolite of azinuth and the height. The aurora duubtless often reaches far up on the sky, and even travels far down on the southern horizon, but the force of light is very small. In spite of the circumstance that Reykjavik lies-judging by the appearance of the aurora borealis on the horizon-much nearer to the auroral maximum zone than Kautokeino, the appearance of the auroræ in the two places cannot be compared. There was activity, force, and colour; here is vagueness, uncertainty, and want of character. Only once-on January 25I observed an aurora during one hour which was a true Arctic one, with defined, elegant outlines, intense play of colour, and bold movements.
The more extensive auroræ which I saw in Kautokeino generally finished by the bands or streamers changing into luminous clouds, which again shortly afterwards assumed the wave-like motion I have called "coruscation," and which often lasted for hours, flooding the entire heavens. This form of the aurora borealis $I$ have not observed on a single occasion here, which appears to me to be a very remarkable circumstance. Extensive auroræ finish here through the simple vanishing of the light or by the changing of the forms into faint, luminous clouds consisting of stripes (north-east to south-west), or vague, cloudy bands which by degrees lose in energy and finally die away.

Any real corona I bave not seen as yet, and the usual colours, viz, red and green, I have only noted on six occasions.

On forty of the eighty-three evenings I bave effected observations there have been auroræ, which is rather a high figure when the unfavourable weather conditions are taken into consideration. But the aurora is, however, not always present when the sky is clear or nearly so; on the contrary, it is not nearly as frequent here as in Kautokeino. This will be understood from Table III., which has been framed on the assumption that all observations were equally divided over the twelve hours, viz. from $4 \mathrm{~h}$. to I $5 \mathrm{~h}$., which also shows that in every hour there was observed one hundred times either aurora or clear sky without aurora. The lower frgures show in per cents. when the sky was without aurora.

TABLE III.

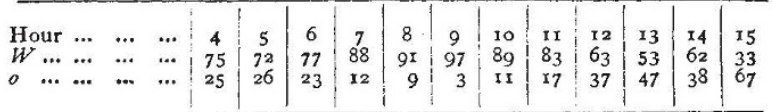

In consequence of the great magnetic declination in Iceland, viz. about $40^{\circ} \mathrm{N}$.W., the points of culmination of the arcs and bands fall far outside the astronomical meridian, and their direction is nearly north-east to south-west. From the measurement of twenty arcs, partly on the north, partly on the south horizon, I have certainly only obtained an azimuth of $22^{\circ} \cdot 4 \mathrm{~W}$., but I do not accept this as any definite result before more complete observations are in my hands.

The intensity of the aurora borealis here I have defined approximately in Table IV. by four degrees, viz. from one to four. From the total determinations of intensity for every hour when no aurora is visible, in spite of clear sky, being determined by 0 , the following average figures are obtained :-

TABLE IV.

\begin{tabular}{lll|l|l|l|l|l|l|l|l|l|l|l|l|l}
\hline Hour $\ldots$ & $\ldots$ & $\ldots$ & 5 & 6 & 7 & 8 & 9 & 10 & Ir & I2 & r3 & I4 $_{4}$ & x 5 & Average
\end{tabular}

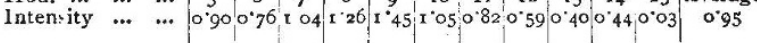

From these figures a decided maximum of intensity is manifest between $g$ b. and roh.

As regards the position of the auroræ on the sky and the relative frequency of the various forms, I append a tabular list of observations. The abbreviations made in the same are these :-

$H N$. Aurora stands near the northern horizon, i.e. the magnetic north.

$l N . \quad$ " , , low in the north.

$N . \quad$ " " " in the north (to a height of about $45^{\circ}$ ).

Nh. " " ", on tbe northern horizon (to a height from

$N h-Z . \quad$ the horizon about $\left.70^{\circ}\right)$.

Further, $Z$ indicates through or on both sides of the zenith $S$, south ; $S Z$, south of zenith ; $S h$, south horizon ; $t$, over the whole sky; $\div$, with the exception of; $N+S$, auroræ in the north and south (but not in zenith); o, no aurora. Below $N^{\prime}$ I have collected the values of $H N, l N, N, N h$, and $N h-Z$; and under $S^{\prime}$ those of $S Z, S h$, and $S$; and under $t^{\prime}$ the others, with the exception of 0 .

Table V. gives percentally, assuming an evenly divided time of observation, a view of the position of the auroræ in the sky.

Table VI. shows the relative appearance of the various forms calculated percentally on the same basis as in the previous tables. Here $I$ indicates one arc ; $I=$, several arcs; $I I$, a band ; $I I=$, several bands; $j$ diffused; $s$, streaming; $j$, simultaneously diffused and streaming, or a variety between the two; III isolated streamers, or bunches of streamers ; $V$, luminous clouds 


\begin{tabular}{|c|c|c|c|c|c|c|c|c|c|c|c|c|c|}
\hline \multicolumn{14}{|c|}{ TABLE V. } \\
\hline Hour & 4 & 5 & 6 & 7 & 8 & 9 & ro & II & 12 & 13 & 14 & 15 & Average \\
\hline$H N$ & 0 & 0 & $\circ$ & $\circ$ & o & 3 & 4 & $r_{3}$ & 5 & o & $\circ$ & $\circ$ & $2 \cdot 2$ \\
\hline lN & $\circ$ & II & $x_{4}$ & 24 & 22 & $\begin{array}{r}3 \\
12\end{array}$ & 25 & 22 & $x 1$ & II & 0 & o & $15^{\circ} \circ$ \\
\hline$N$ & 8 & 37 & $3 I$ & 26 & 22 & 19 & 21 & 9 & II & 0 & $\circ$ & 33 & $19^{-8}$ \\
\hline$N h$ & 8 & 5 & 6 & 2 & 3 & 0 & 7 & o & 0 & $\circ$ & $\circ$ & 0 & $2 \%$ \\
\hline$N h-Z$ & 8 & o & 3 & $\mathrm{I}^{2}$ & 9 & 9 & 7 & $\circ$ & $\circ$ & 5 & 13 & o & 6.2 \\
\hline$N h-S Z$ & 8 & 5 & 6 & $x^{2}$ & 16 & 19 & 4 & 9 & 5 & II & 25 & o & $10 \cdot 3$ \\
\hline$Z$ & ० & 0 & 0 & 2 & $\epsilon$ & o & 7 & 0 & 0 & 5 & 13 & o & $2 \cdot 6$ \\
\hline$S Z$ & $\circ$ & $\circ$ & 3 & 2 & $\circ$ & 3 & o & $\circ$ & $\circ$ & o & o & o & $r \cdot I$ \\
\hline$S h$ & 8 & o & 0 & 5 & 0 & 0 & 0 & $\circ$ & $\circ$ & $\circ$ & $\circ$ & o & $I^{\prime} I$ \\
\hline$S$ & 8 & o & o & 2 & $\circ$ & 3 & 4 & 。 & 5 & o & $\circ$ & $\circ$ & 1.8 \\
\hline$t \div(N+S)$ & 8 & o & 3 & $\circ$ & 3 & 6 & o & $\circ$ & 5 & o & $\circ$ & 。 & $2 \cdot 2$ \\
\hline$t \div i s$ & 0 & 5 & o & 2 & 3 & 9 & 4 & 9 & 5 & 16 & $\circ$ & $\circ$ & 48 \\
\hline$t \div I N$ & $\circ$ & o & $\circ$ & 2 & o & 0 & $\circ$ & 0 & $\circ$ & $\circ$ & $\circ$ & $\circ$ & 0.4 \\
\hline$N+S$ & 8 & $\circ$ & 6 & 2 & 6 & 3 & 4 & 9 & 5 & o & $\circ$ & $\circ$ & $4 \%$ \\
\hline$t$ & 8 & II & 6 & 5 & $\circ$ & 6 & 4 & $x_{3}$ & XI & 5 & 13 & $\circ$ & $6 \cdot 2$ \\
\hline o & 25 & 26 & 23 & 12 & 9 & 3 & II & I7 & 37 & 47 & 38 & 67 & $19 \%$ \\
\hline$N^{\prime}$ & 25 & 53 & 54 & 53 & 56 & 47 & 64 & 43 & 26 & 16 & $x_{3}$ & 33 & $46 \cdot 2$ \\
\hline$S^{\prime}$ & 17 & $\circ$ & 3 & 9 & $\circ$ & 6 & 4 & 0 & 5 & 0 & $\circ$ & 0 & 40 \\
\hline$t^{\prime}$ & 23 & 16 & 20 & 26 & 34 & 44 & $2 \mathrm{I}$ & 39 & $3^{2}$ & 37 & 50 & o & $30 \% 4$ \\
\hline$S^{\prime}+t^{\prime}$ & 50 & 16 & 23 & 35 & 34 & 50 & 25 & 39 & 37 & 37 & 50 & o & $34 \cdot 4$ \\
\hline
\end{tabular}

TABLE VI.

\begin{tabular}{|c|c|c|c|c|c|c|c|c|c|c|c|c|}
\hline Hour & 4 & 5 & 6 & 7 & 8 & 9 & ro & II & 12 & $I_{3}$ & I4 & Tctal \\
\hline $\begin{array}{l}I j \\
I S \\
I j s \\
I I j \\
I I s \\
I I j s \\
I I I \\
V \\
I=j \\
I=s \\
I=j s \\
I I=j \\
I I=s \\
I I=j s\end{array}$ & $\begin{array}{c}3 \cdot 3 \\
0 \\
3 \cdot 3 \\
0 \\
0 \\
0 \\
0 \\
0 \\
0 \\
0 \\
3 \cdot 3 \\
0 \\
3.3 \\
6.7 \\
\end{array}$ & 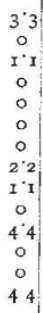 & \begin{tabular}{c|c|}
4 & 6 \\
0 \\
1 & 5 \\
0 \\
0.8 \\
0 \\
0.8 \\
$1 \cdot 5$ \\
2.3 \\
0.8 \\
$1 \cdot 5$ \\
$1 \cdot 5$ \\
0.8 \\
2.3
\end{tabular} & 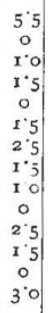 & $\begin{array}{c}4.0 \\
0 \\
20 \\
0 \\
0 \\
27 \\
0.7 \\
17 \\
07 \\
07 \\
07 \\
27 \\
0 \\
07 \\
40 \\
40\end{array}$ & $\begin{array}{c}29 \\
0 \\
2 \cdot 4 \\
0 \\
06 \\
1 \cdot 2 \\
0.6 \\
r^{2} 2 \\
x^{2} 2 \\
0 \\
2 \cdot 9 \\
0 \\
0.6 \\
3.5\end{array}$ & 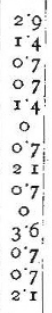 & $\begin{array}{c}0.8 \\
x \cdot 7 \\
2.5 \\
x \cdot 7 \\
0 \\
0.8 \\
3.3 \\
2.5 \\
0 \\
0.8 \\
2.5 \\
1.7 \\
0 \\
0.8\end{array}$ & $\begin{array}{cc}2 & 2 \\
1 & 1 \\
2 & 2 \\
1 & 1 \\
0 & 1 \\
0 & 1 \\
1 & 1 \\
I & I \\
3 & 3 \\
0 & \\
0 \\
2 \cdot 2 \\
0 \\
I \cdot I \\
0\end{array}$ & \begin{tabular}{c|c|}
$r$ & 3 \\
0 \\
$r$ & 3 \\
$r$ & 3 \\
$r$ & 3 \\
$r$ & 3 \\
$r$ & 3 \\
$r$ & 3 \\
5 & 0 \\
0 \\
0 \\
$r \cdot 3$ \\
0 \\
0 \\
0
\end{tabular} & \begin{tabular}{|c|c|}
0 \\
2 & 0 \\
0 \\
2 & 0 \\
0 \\
0 \\
0 \\
20 \\
0 \\
0 \\
0 \\
0 \\
40 \\
20 \\
0
\end{tabular} & $\begin{array}{r}30^{\circ} 8 \\
6.2 \\
18.0 \\
8.3 \\
4^{\circ} .1 \\
8.6 \\
111^{\circ} 0 \\
22.6 \\
7.0 \\
20^{\circ} 3 \\
26.9 \\
9.4 \\
9.2 \\
26.8\end{array}$ \\
\hline $\begin{array}{c}I \\
I I \\
j \\
s \\
j s\end{array}$ & $\begin{array}{r}100 \\
3.3 \\
3.3 \\
13.3 \\
13.3\end{array}$ & $\begin{array}{c}4.4 \\
44 \\
0 \\
10^{\circ}\end{array}$ & 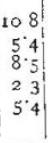 & $\begin{array}{r}\text { ro. } \\
7.5 \\
9.5 \\
0.5 \\
0 \\
8.0\end{array}$ & $\begin{array}{r}\text { ro.0 } \\
7.3 \\
47 \\
4.3 \\
\text { II } 3\end{array}$ & \begin{tabular}{rr|}
9 & 4 \\
5 & 9 \\
4 & $\mathrm{r}$ \\
$\mathrm{r} \cdot 2$ & 2 \\
10 & 0
\end{tabular} & $\begin{array}{l}9 \cdot 3 \\
5 \cdot 7 \\
5 \cdot 0 \\
3 \cdot 6 \\
6 \cdot 4\end{array}$ & $\begin{array}{l}8.3 \\
5.0 \\
4.2 \\
25 \\
6.7\end{array}$ & \begin{tabular}{ll|}
7 & 8 \\
3 & 3 \\
3 & 3 \\
3 & 3 \\
5 & 3 \\
5 & 6
\end{tabular} & $\begin{array}{l}3.8 \\
3.8 \\
2.5 \\
1.3 \\
3.8\end{array}$ & $\begin{array}{l}20 \\
80 \\
60 \\
40 \\
0\end{array}$ & $\begin{array}{l}90^{\circ} \cdot 4 \\
66.3 \\
55.5 \\
22.8 \\
80.5\end{array}$ \\
\hline
\end{tabular}

On the valuable isochasme chart, in which Prof. Fritz has denoted the increasing frequency of the aurora borealis northwards, the maximum zone of the phenomenon falls far south of Iceland. I must, however, first explain what my definition of the word maximum zone is at present. It is a line passing across the places where the aurora not only appears and is most frequently visible, provided the weather permits, but where it also, as a rule, appears in zenith, or as often on the northern as the southern hemisphere. According to this definition, the correctness of which I think can neither be disputed nor doutted, Iceland lies, at all events this year, as was the case with Kautokeino and Bossekop last year, considerably south of the maximum zone, which is, in fact, clearly shown in Table V.

I hope to be able to demonstrate this in a more conclusive manner still on a future occasion, when the winter is over and the numerous exact determinations of the southern border of the aurora borealis will be discussed.

The reason why the maximum zone lies so far south on Prof. Fritz's chart may be sought, perhaps, in the circumstance that the climatic conditions of Iceland to a great extent reduce the number of auroræ which an ordinary observer, who only casually or on particular occasicns looks at the sky, may observe. That the maximum zone of the aurora does not really fall across the part shown in the chart is also distinctly apparent from what I learnt of its appearance at the Färoe Islands during my sojcurn there.

It may perhaps be superfluous to state that neither here nor in any other place have I heard the mystic auroral sound. Neither has it ever been heard by any of the Icelanders I have as yet met with.

Shortly before leaving Copenhagen last autumn I spoke with a celebrated Danish savant, who had some years ago spent some time in Reykjavik, and $v$ ho told me that he had on several occasions seen auroræ descend below and in front of the mountain Esja, about 2500 feet in height, and lying six to seven English miles away (NATURE, vol. xxix. p. 337). I was de- lighted with the prospect of being able to see a similar pbenomenon, as, although my observations in the plane Bossekop. Kautokeino, previously referred to, had greatly contributed to strengthen my belief in the height of the aurora borealis being $100 \mathrm{~km}$, or more above the earth (NATURE, vol. xxix. p. 4I2), I would with pleasure have accepted a proof so tangible pointing in ar other direction. I regret to say that my expectations have not been fulfilled. This is not kecause the aurora has not been in close proximity to Esja, as, the mountain lying to the north-east from this place, nearly all ares and bands rise with their eastern end up behind and run above it, but never have $I$ been so fortunate as to see any auroral light descend to the top of the mountain or in front of its steep sides. Even the highestlying clouds are also, in Iceland, below the plane of the aurora borealis.

In connection with this point I may further mention that the faint luminosities referred to by Prof. Lemström above the mountain-tops at Sodankylä, and in other places (NATURZ, vol. xxvii. p. 322), as well as phenomena of a similar nature have, I venture to assert, never been observed here. I have continually had my attention directed to this point, and there are several mountains here, but $I$ have never been able to trace the slightest indication of such a phenomenon.

I brought with me the necessary apparatus and appliances for effecting such experiments as Prof. Lemström pursued on some mountains in Northern Finland for the production of an artificial aurora borealis, and shortly after my arrival I came to the conclusion that the above-mentinned mountain Esja was the most advantageous for such. Its great height, steep fall into the sea, and short distance from the town, were advantages such as no other spot in the district offered, but as I only brought with me $1000 \mathrm{~m}$. of insulated wire-telegraph-poles with insulators cannot be employed in consequence of the nature of the ground -and wished to conduct the wire from the top of the mountain down 10 the sea at its foot, I was obliged to wait until I obtained more wire by the steamer at the end of November. Since then the execution of this plan has been attempted a number of times; men, boats, and horses have heen ready, and everything prepared, but every time the unfortunate weather has frustrated the same. Even in the middle of summer the Esja is a mountain difficult to ascend, and at this time of the year it would be very dangerous to undertake an ascent with the heavy wires, insulators, and poles, without the weather being remarkably quiet for several days.

I intend, however, very shortly to make another attempt, and should this fail I will select a more distant but much lower and more unfavourably situated mountain top. I will only add that a few days after my arrival I fixed one of Prof. Lemström's "utströmnings" apparatus-with 200 points-on the flat roof of a stone tower, 30 to 40 feet in height, and which lies free and isolated on a heiuht in the vicinity of the town; but the same has up to the present, in spite of numerous trials, given no result whatever. Any current between the points and the earth cannot be traced, and of any luminous phenomena above them there has not been the faintest appearance. SOPHUS TrOMHOLT

Reyljavik, February

\section{ON THE NATURAL AND ARTIFICIAL FERTILISATION OF HERRING OVA ${ }^{1}$}

IN 1862 Prof. Huxley arrived at the conclusion that herring visit our shores in order to spawn twice a year, some schools arriving during the autumn, while others make their appearance during the winter. The herring which spawn during the autumn chiefly frequent banks on the east coast, while those which spawn during winter are most abundant on the west coast. A report of the Scottish Fishery Board referring to the east coast spawning beds was published in NATURE on November 29 last. The present paper deals chiefly with the Ballantrae spawning bed, which lies off the coast of Ayrshire.

In 1862 Prof. Allman made some investigations for the Scottich Fishery Board, and succeeded in dredging and hatching what was considered herring ova ; but since then, although important results have been obtained by the German and American Commissioners of Fisheries, little or nothing has been done in this country.

When examining the Ballantrae Bank the author of this paper succeeded in dredging several specimens of herring ova aitached

I Abstract of a paper read by Prof. J. Cossar Ewart, M.D., at the Royal Society, March 27. Communicated by the Author. 